\title{
Can we extrapolate the outcomes of in vitro studies on murine endothelium to studies of human platelet-endothelium interactions? A technical note
}

Jacek Golański', Marta Michalska², Joanna Polowinczak-Przybyłek ${ }^{3}$, Urszula Krajewska ${ }^{4}$, Cezary Watała ${ }^{1}$

\author{
1Department of Haemostasis and Haemostatic Disorders, Medical University of Lodz, \\ Poland \\ 2Department of Hypertension, Medical University of Lodz, Poland \\ ${ }^{3}$ Department of the Proliferative Diseases, Regional Oncological Centre in Lodz, Poland \\ ${ }^{4}$ Molecular Biology Laboratory, Department of Pharmaceutical Biochemistry, \\ Medical University of Lodz, Poland
}

Submitted: 14 August 2009

Accepted: 21 September 2009

Arch Med Sci 2011; 7, 1: 34-37

DOI: 10.5114/aoms.2011.20601

Copyright @ 2011 Termedia \& Banach

\begin{abstract}
Introduction: Interactions between vascular endothelium and blood platelets play a crucial role in cardiovascular diseases. Ex vitro models which use endothelial cells and platelets were the essential tools to investigate these interactions and their impact on haemostasis. The impaired interplay between vascular endothelium, blood platelets and leukocytes is believed to contribute to the development of cardiovascular disease. In this study we compared the ability of human (HUVECS) and murine (HECa10) endothelial cells to inhibit human platelet function and reactivity under in vitro conditions.

Material and methods: The aliquots of platelet-rich plasma obtained from 20 healthy donors were incubated with murine endothelial cell line HECa10 or human umbilical vein endothelial cells (HUVECs) $\left(10 \mathrm{~min}, 37^{\circ} \mathrm{C}\right)$ prior to agonizing platelets with $5 \mu \mathrm{M}$ ADP and monitoring platelet reactivity for 10 min using optical aggregation.

Results: Significant reduction in ADP-induced platelet aggregation in the presence of endothelial cell cultures remained independent of cell count. HUVECs appeared much more effective in the inhibition of platelet aggregation compared to HECa10 ( $35.2 \pm 2.3 \mathrm{AU}$ vs. $43.7 \pm 2.0 \mathrm{AU}, p=0.025)$.

Conclusions: HECa10 cells have much lower potential to inhibit platelet aggregation than HUVECs. This implies that these two cell lines may not be freely used interchangeably in in vitro experiments. These findings clearly indicate that the outcomes of in vitro studies performed with murine EC lines cannot be unreservedly extrapolated to human platelet-endothelium interactions.
\end{abstract}

Key words: endothelial cells, platelet aggregation.

\section{Introduction}

Vascular endothelium plays a major role in the inhibition of platelet activation. This way it protects blood vessels against thrombosis [1]. The modulation of platelet reactivity using endothelial cells has been proven to constitute a useful model for investigation of haemostatic mechanisms [2] and in the research on antithrombotic agents [3]. Murine endothelial cell lines offer an interesting perspective for studying

\author{
Corresponding author: \\ Prof. Cezary Watała, PhD \\ Department of Haemostasis \\ and Haemostatic Disorders \\ Medical University of Lodz \\ 113 Zeromskiego \\ 90-549 Lodz, Poland \\ Phone: +48 426393471 \\ Fax: +48 426787567 \\ E-mail: \\ cwatala@csk.umed.lodz.pl
}


endothelial pathophysiology and pharmacology, and murine models of endothelium-platelet interactions have been occasionally employed earlier [4]. However, there are no literature reports on the modulation of human platelets by murine endothelial lines. Due to some problems and obstacles occurring with human endothelial cell cultures we may consider the application of murine endothelial cell lines as simple and not expensive models for studying pharmacological aspects of interactions of blood cells and vascular endothelium.

The principal aim of this work was to compare the ability of HUVECs (human umbilical vein endothelial cells) and murine HECa10 (murine endothelial cell line [immortalized hepatic endothelial cells - clone HECa10]) to inhibit platelet aggregation monitored under in vitro conditions and to evaluate how far these two cell lines may be used exchangeably in the in vitro model studies with a possible extrapolation to human pathophysiology and pharmacology.

\section{Material and methods}

\section{Reagents}

The platelet agonist ADP was from Chrono-Log (Havertown, PA USA).

Unless stated otherwise, all other chemicals were from Polish Chemical Reagents (Gliwice, Poland).

\section{Blood collection}

Blood was collected from 20 healthy donors (9 men and 11 women, mean age $27.5 \pm 11.5$ years) into a vacuum tube (Vacutainer ${ }^{\top M}$, Becton Dickinson, San Diego, CA, USA) containing buffered $0.105 \mathrm{M}$ sodium citrate (the final citrate : blood ratio was $1: 9 \mathrm{vol} / \mathrm{vol})$. Blood was withdrawn with special caution to avoid undesirable activation of circulating platelets. Blood was centrifuged for $6 \mathrm{~min}$ at $250 \times$ g to obtain platelet-rich plasma. In all experiments platelet count in plasma was adjusted to $2 \times 10^{8}$ platelets $/ \mathrm{ml}$ prior to use.

The study was performed under the guidelines of the Helsinki Declaration for human research and approved by the committee on the Ethics of Research in Human Experimentation at the Medical University of Lodz (No. RNN/13/07/KB).

\section{Cell cultures}

The murine endothelial cell line HECa10 (immortalized Hepatic Endothelial Cells - clone HECa10), a kind gift to our laboratory from Dr Claudine Kieda (Orléan, France), was used in experiments. HEC were isolated from endothelium of mouse peripheral lymph nodes immortalized by transfection which involved using a plasmid construct containing both the gene coding for the large $T$ antigen of simian virus 40 and a geneticin resistance gene [5].

The continuous culture of cells was maintained in culture flasks (Nunc EasY Flasks $25 \mathrm{~cm}^{2}$, NUNC). Cells were cultured in RPMI 1640 medium (Sigma) supplemented with $25 \mathrm{mM}$ Hepes buffer (Sigma), $2 \mathrm{~g} / \mathrm{l}$ sodium bicarbonate (Sigma), $50 \mu \mathrm{M}$ 2-mercaptoethanol (Sigma), $4 \mathrm{mM}$ L-glutamine (Sigma), $100 \mathrm{U} / \mathrm{ml}$ penicillin and $100 \mu \mathrm{g} / \mathrm{ml}$ streptomycin solution (Sigma), $0.1 \mathrm{mM} \mathrm{MEM}$ nonessential amino acid solution (Sigma), $1 \mathrm{mM}$ sodium pyruvate (Sigma), and 10\% heat-inactivated fetal calf serum (FCS, Biochrom) (complete RPMI), and were kept at $37^{\circ} \mathrm{C}$ in a humidified atmosphere of $95 \%$ air and $5 \% \mathrm{CO}_{2}$. Twice a week, prior to confluency, cells were harvested after 2-min incubation at room temperature in the presence of trypsin-EDTA (0.05 and $0.02 \%$ respectively) in Hanks-balanced salt solution (Sigma). Cells were collected, washed three times in complete RPMI, centrifuged and seeded at $1 \times 10^{5}$ cells $/ \mathrm{ml}$ of the fresh medium [6].

Human Umbilical Vein Endothelial Cells (HUVECS) and all reagents needed for cell culture were purchased from Cascade Biologics (Portland, Oregon, USA). HUVECs were cultured according to the manufacturer's instructions and cells underwent 2-10 passages. In platelet aggregation studies, both HUVECS and HECa10 were suspended in Medium 200 at decreasing cell counts and, finally, the amount of HUVECs in PRP was $9.9 \times 10^{3}$ cells $/ \mathrm{ml}$ or $6.6 \times 10^{3}$ cells $/ \mathrm{ml}$ or $3.3 \times 10^{3}$ cells $/ \mathrm{ml}[3]$.

\section{Measurements of platelet reactivity}

The platelet-rich plasma (PRP $-2 \times 10^{8}$ platelets $/ \mathrm{ml})$ was incubated $\left(10 \mathrm{~min}, 37^{\circ} \mathrm{C}\right)$ in aggregation cuvettes with HUVECs or HECa10 suspended in Medium $200\left(3.3 \times 10^{3}\right.$ cells $\left./ \mathrm{ml}\right)$ without supplements. Medium 200 was used as a controlling agent. In the first experiment we investigated the ability of various HUVEC suspensions to inhibit platelet aggregation. In the base experiment HUVECs were compared with HECa10. The ability to inhibit platelet functions was evaluated after incubation of $\left(10 \mathrm{~min}, 37^{\circ} \mathrm{C}\right)$ HUVECs or HECa10 with aliquots of PRP originating from the same healthy donors.

Platelet reactivity, in the presence of $5 \mu \mathrm{M}$ ADP, was monitored for 10 min using an optical aggregation method (Chrono-Log 490-2D, Havertown, PA, USA) and aggregation curves were analysed using the software "Platelet Aggregation Monitoring and Analysis" (PAMA) [7]. The value of maximal light transmission, $A_{\max }$, reflecting the extent of maximal platelet aggregation, was used for further data analysis. 


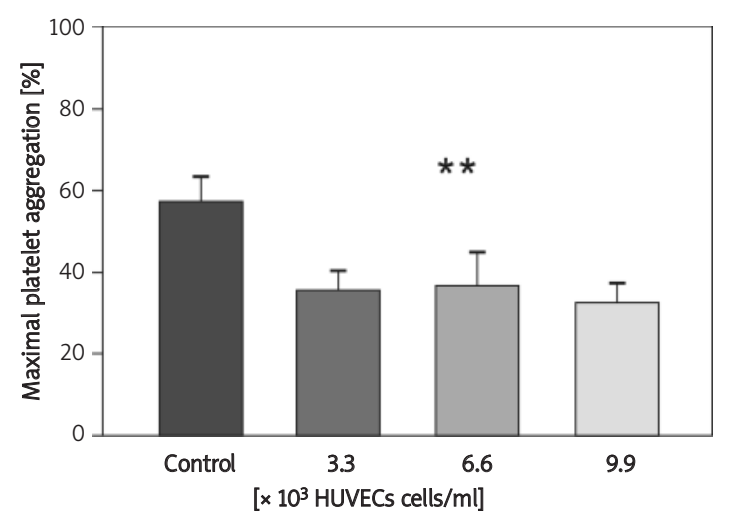

Figure 1. The effect of various endothelial cells (HUVEC) count on ADP-induced (5 $\mu \mathrm{M})$ platelet aggregation monitored under in vitro conditions. Data shown as mean \pm SEM. Significance of differences estimated with Tukey multiple comparisons test

Control $\neq$ all HUVECS cell counts, $p<0.00011^{(*)}$

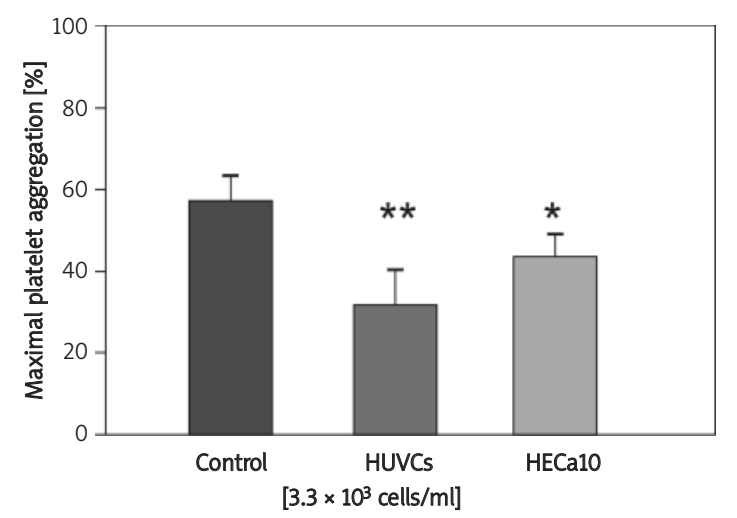

Figure 2. Comparison of the ability of human endothelial cells (HUVECs) vs. murine endothelial cells (HECa10) to inhibit ADP-induced (5 $\mu \mathrm{M})$ platelet aggregation monitored under in vitro conditions. Data shown as mean \pm SEM. Significance of differences estimated with the post hoc Tukey test for multiple comparisons

Control $\neq$ HUVECs, $p<0.0001{ }^{(* *)}$

Control $\neq$ HECa10, $p=0.002\left(^{*}\right)$

HUVECS $\neq$ HECa10, $p=0.025(* *)$

\section{Statistical analysis}

Data are presented as mean \pm SEM (standard error of the mean). The Shapiro-Wilk test was used to verify whether data were normally distributed and Tukey multiple comparisons test was employed to estimate the significance of differences between groups.

\section{Results}

This study encompasses two lines of experiments. In the first line we observed a significant reduction in ADP-induced platelet aggregation in the presence of HUVECs. Interestingly, this effect was independent of the cell count in endothelial cell cultures (Figure 1).
In earlier work we applied a relatively high concentration of ADP $(10 \mu \mathrm{M})$ and in the present work we used $5 \mu \mathrm{M}$ ADP for platelet aggregation. So we were afraid to overlook expected (subtle) differences between tested endothelial cell lines. In actual experimental conditions we observed a much stronger inhibitive activity of endothelial tissue. This took place once we used a lower concentration of ADP ( $5 \mu \mathrm{M}$ ADP) than in the previous experiment. It is worth noting that the prior test required use of a higher concentration of ADP (10 $\mu \mathrm{M}$ ADP).

In another series of experiments we also revealed a significant antiplatelet effect on both HUVECS and HECa10. Both endothelial cell lines significantly inhibited ADP-induced platelet aggregation (Figure 2). To compare the ability of HUVECs and HECa10 to inhibit platelet aggregation stimulated by ADP we chose the suspension of $3.3 \times 10^{3}$ cells $/ \mathrm{ml}$.

In our earlier studies we showed the inhibitory effect of endothelial cells (EC) on blood platelets depending on the EC count. The first effective count which inhibits platelet aggregation was $3.3 \times 10^{3}$ cells $/ \mathrm{ml}$. We employed the examined murine EC line at the same cell count in the present study accordingly.

What is noteworthy, murine endothelial cells inhibited human platelet aggregation to a considerably weaker extent than human endothelial cells (Figure 2).

\section{Discussion}

The available literature shows a large variety of different protocols and methodological approaches employed for studying murine models to investigate endothelial physiology $[8,9]$ and platelet-endothelium interactions [1, 3, 10-13]. Most researchers applied HUVEC cells when conducting such studies $[3,14-16]$, although the murine endothelial cell line HECa10 was also occasionally used earlier [5, 6, 17]. However, it is the first study with the mixed model, i.e. using a murine endothelial cell line and human blood platelets for studying platelet-endothelium interactions. In our present study we used low concentrations of ADP as a platelet agonist that is known to activate both platelets (activation and aggregation) and endothelial cells via $\mathrm{P} 2 \mathrm{Y}$ receptors [18]. Our data are consistent with what we demonstrated in our recent report, in which we showed the inhibition of ADP-induced platelet aggregation by HUVEC cells and revealed that the effect was endothelial cell count dependent [3]. In our present report we have not evidenced such a distinct effect of cell count in the endothelial cell cultures on platelet aggregation, which in our opinion most likely results from the apparently low concentration of ADP used in this experiment to stimulate blood platelets. 
When comparing the inhibitory effectiveness of EC originating from different species, we revealed that murine endothelial cell line HECa10 was significantly less effective in hampering human blood platelet aggregation. The mechanism(s) of such difference(s) has not been extensively explored in the present study. On the basis of our results and literature data we cannot explain in depth the origin of observed differences between murine and human endothelial cell lines [19]. We have formulated a "general" warning addressed to researchers who extrapolate the outcomes of in vitro studies on murine endothelium to studies of human platelet-endothelium interactions.

Our observation deserves to be emphasized in regard to potential exchangeability of the outcomes of model studies using animal cell cultures, as a cheaper substitute for cell cultures of human origin. Although useful in some physiological studies, the outcomes of studies performed on such models may not be unreservedly extrapolated to discuss any further perspectives in human medicine.

Thus, our present findings may bear some disappointing implications for direct extrapolation(s) of results collected using animal cell cultures to target particular pharmacological scenarios in humans.

\section{Acknowledgments}

This study was supported by project N405 065034 of the Polish Ministry of Science and Higher Education; grant 502-16-651 was supported by the Medical University of Lodz.

\section{References}

1. Siegel-Axel DI, Gawaz M. Platelets and endothelial cells. Semin Thromb Hemost 2007; 33: 128-35.

2. Cha YJ, Chang EA, Kim CH. Effects of endothelial cells and mononuclear leukocytes on platelet aggregation. Haematologia (Budap) 2000; 30: 97-106.

3. Luzak B, Golanski J, Rozalski M, Krajewska U, Olas B, Watala C. Extract from Aronia melanocarpa fruits potentiates the inhibition of platelet aggregation in the presence of endothelial cells. Arch Med Sci 2010; 6: 141-4.

4. Carrier E, Brochu I, De Brum FA, D'Orleans-Juste P. The inducible NOS modulates Endothelin-1-dependent release of prostacyclin and inhibition of platelet aggregation ex-vivo in the mouse. J Pharmacol Exp Ther 2007; 323: 972-8.

5. Bizouarne N, Denis V, Legrand A, Monsigny M, Kieda C. A SV-40 immortalized murine endothelial cell line from peripheral lymph node high endothelium expresses a new alpha-L-fucose binding protein. Biol Cell 1993; 79: 209-18.

6. Lawnicka H, Stepien H, Wyczolkowska J, Kolago B, Kunert-Radek J, Komorowski J. Effect of somatostatin and octreotide on proliferation and vascular endothelial growth factor secretion from murine endothelial cell line (HECa10) culture. Biochem Biophys Res Commun 2000; 268: $567-71$
7. Golanski J, Golanski R, Iwaszkiewicz A, Chlopicki S, Gresner $P$, Watala C. Resistance to aspirin in patients after coronary artery bypass grafting is transient. Impact on the monitoring of aspirin antiplatelet therapy. Therap Drug Monit 2005; 27: 484-90.

8. Schuepbach RA, Feistritzer C, Fernandez JA, Griffin JH, Riewald M. Protection of vascular barrier integrity by activated protein C in murine models depends on protease-activated receptor-1. Thromb Haemost 2009; 101: 724-33.

9. Bzowska M, Stalinska K, Mezyk-Kopec R, et al. Exogenous nitric oxide inhibits shedding of ADAM17 substrates. Acta Biochim Pol 2009; 56: 325-35.

10. Greenlees C, Wainwright CL, Wadsworth RM. Vasorelaxant and antiaggregatory properties of the endothelium: a comparative study in normocholesterolaemic and hereditary and dietary hypercholesterolaemic rabbits. $\mathrm{Br}$ J Pharmacol 1996; 119: 1470-6.

11. Kaplan JE, Moon DG, Weston LK, et al. Platelets adhere to thrombin-treated endothelial cells in vitro. Am J Physiol 1989; 257: H423-33.

12. Korbut R, Ocetkiewicz A, Dabros W, Gryglewski RJ. A biological method for studying the interaction between platelets and vascular endothelium. Thromb Res 1990; 57: 361-70.

13. Ohlstein EH, Storer BL, Butcher JA, Debouck C, Feuerstein G. Platelets stimulate expression of endothelin mRNA and endothelin biosynthesis in cultured endothelial cells. Circ Res 1991; 69: 832-41.

14. Cumashi A, Ushakova NA, Preobrazhenskaya ME, et al. A comparative study of the anti-inflammatory, anticoagulant, antiangiogenic, and antiadhesive activities of nine different fucoidans from brown seaweeds. Glycobiology 2007; 17: 541-52.

15. Brueckmann M, Horn S, Lang S, et al. Recombinant human activated protein $C$ upregulates cyclooxygenase-2 expression in endothelial cells via binding to endothelial cell protein $\mathrm{C}$ receptor and activation of protease-activated receptor-1. Thromb Haemost 2005; 93: 743-50.

16. Chudzinski-Tavassi AM, Schattner M, Fritzen M, et al. Effects of lopap on human endothelial cells and platelets. Haemostasis 2001; 31: 257-65.

17. Polowinczak-Przybylek J, Melen-Mucha G. The inhibitory influence of adiponectin on the growth of the murine endothelial cell line HECa 10 in vitro. Endokrynol Pol 2009; 60: $166-71$

18. Andre P, LaRocca T, Delaney SM, et al. Anticoagulants (thrombin inhibitors) and aspirin synergize with P2Y12 receptor antagonism in thrombosis. Circulation 2003; 108: 2697-703.

19. Houser SL, Benjamin LC, Wain JC, Madsen JC, Allan JS. Constitutive expression of major histocompatibility complex class II antigens in pulmonary epithelium and endothelium varies among different species. Transplantation 2004; 77: 605-7. 